\title{
PREVALENCE AND DETERMINANTS OF UNINTENDED PREGNANCY AMONG WOMEN IN SOUTH-WESTERN NIGERIA
}

\author{
M. A. LAMINA \\ Maternal and Fetal Health Unit, Department Of Obstetrics and Gynaecology, Olabisi Onabanjo University \\ Teaching Hospital, Sagamu, Nigeria
}

DOI: http://dx.doi.org/10.4314/gmj.v49i3.10

Corresponding Author: Dr. Mustafa Adelaja Lamina

E-mail: ademustapha_2003@yahoo.co.uk

Conflict of Interest: None declared

\section{SUMMARY}

Objective: To study the prevalence of unwanted pregnancy in urban and rural settlements in Southwestern Nigeria.

Design: A prospective cross-sectional study of women within reproductive age.

Setting: Community-based study of unwanted pregnancy was conducted in 2012.

Participants: They were women of reproductive age who had experienced unintended and/or unwanted pregnancies and they were randomly selected from rural and urban areas of Ogun state in Nigeria. Intervention: A semi-structured questionnaire was used for data collection.

Main outcome measure: The prevalence of unintended/unwanted pregnancy, associated factors including the views, perception and attitudes of community members in both urban and rural settlements and the pattern of help-seeking behavior on the problem. Results: The age range of respondents was 15-48 years (mean age 31.2 \pm 6.7 years). One thousand, two hundred and twenty-one $(51.6 \%)$ of the respondents were married. The percentage of illiterate respondents was $3.5 \%$ in urban area and $4.1 \%$ in rural area. There was a statistically significant association between level of education and use of a method to avoid or delay pregnancy $(\mathrm{p}<0.001)$. The prevalence of unintended pregnancy was $35.9 \%$ while that of induced abortion was $33.5 \%$. Quality of service was the most important factor in the choice of a place for pregnancy termination in urban and rural areas. Economic reasons were often cited as reasons women make use of abortion services. Conclusion: Unwanted pregnancy constitutes a problem, even at the community level. The high contraceptive awareness should be translated to an increased use so as to bridge the large gap of unmet need.

Keywords: Unintended pregnancy; induced abortion; determinants; contraception; urban area; rural area; Nigeria

\section{INTRODUCTION}

Unintended intercourse is the primary cause of unwanted pregnancies in Nigeria, and many women with unwanted pregnancies from unintended intercourse decide to end them by abortion. ${ }^{1}$ The prevalence of unintended pregnancy in Nigeria is high. A study carried out in two states of Southwestern Nigeria by OyeAdeniran et al. reported a prevalence rate of unwanted pregnancy of $26.6 \%$ and abortion prevalence of $21.7 \%^{2}$. Since abortion is illegal in Nigeria (unless medically recommended to save a mother's life), many abortions are carried out in an unsafe environment ${ }^{3}$. The consequences of these clandestine abortions are grave and can be life-threatening, often leading to maternal death. $^{2-4}$

Abortion accounts for $20 \%-40 \%$ of maternal deaths in Nigeria. ${ }^{2-4}$ An estimated 610,000 abortions are reported to occur in Nigeria annually. ${ }^{5}$ Unwanted pregnancy occurs in women of all ages but adolescents have been most affected. ${ }^{2,6}$ It has been reported that by the age of 45 years most women would have had at least one abortion. $^{5,7}$

Married women also experience unwanted pregnancy, as they constituted $34.8 \%$ and $63.2 \%$ of abortion seekers in two studies respectively from Southwestern Nigeria. $^{2,8}$

It has been reported that some women use abortion as a means of child spacing instead of contraception. ${ }^{9}$ This may be as a result of low contraceptive prevalence rates despite reported high contraceptive awareness and enlightenment drives. 2 Many factors contribute to unwanted pregnancy in Nigeria, and a very important factor is the low level of contraceptive use. ${ }^{10-12}$ In addition, a desire to limit family size to enable the family to provide a better education for the children, the increased participation of women in the labor force, and urbanization are other factors leading to the desire of Nigerian women to have a predetermined number of children. $^{13}$ 
It is obvious therefore that abortion is no longer a prerogative or problem of any single group of women. In spite of this, most studies on unwanted pregnancy and abortion have been hospital-based. The impact, prevalence and ways women deal with unwanted pregnancy in the community are driven more to the background. A few studies that have tried to assess the prevalence of unwanted pregnancy and abortion in the communi$\mathrm{ty}^{5,8,14}$ have found that it presents a problem of considerable magnitude. There is a need to conduct a study of this profile (involving both rural and urban dwellers) in order to increase community awareness on the extent of this calamity.

In a 1994 study to document the magnitude of unsafe abortion complications in Commonwealth member countries by the Commonwealth Regional Health Community Secretariat, one of the major research needs identified were community-based epidemiological studies. ${ }^{15}$ In Nigeria, the prevalence and determinants of unintended pregnancy among women in diverse social and economic situations, in both urban and rural areas, are poorly understood due to lack of data.

This study therefore seeks to study the prevalence of unwanted pregnancy in the community. It is also aimed at determining the associated factors including the views, perception and attitudes of community members towards unwanted pregnancy in both urban and rural settlements in Southwestern Nigeria. In addition, the pattern of help-seeking behavior on the problem will be sought.

\section{SUBJECTS AND METHODS Study setting}

This community-based study of unwanted pregnancy was conducted in 2012 in urban and rural areas of Ogun State of Nigeria. Despite the restrictive law on abortion in Nigeria, women give information on induced abortion as evidenced by records from antenatal clinics. This is more so when trained interviewers are used and confidentiality is ensured as it was in this study. The Ethics and Research Review Committee of Olabisi Onabanjo University Teaching Hospital (OOUTH), Sagamu, Nigeria approved this study.

\section{Sample size}

Various factors were taken into consideration in determining the minimum sample size. Among them was the need for the study size to be able to address all the research objectives. Eventually, the largest sample size that satisfied all objectives was used. This was the objective that sought to compare the prevalence of abortion between urban and rural areas of Ogun State. The following formula for sample size for comparative studies was used: Sample size per group $=\underline{p}_{1}\left(1-p_{1}\right)+$ $\underline{\mathrm{p}}_{2}\left(1-\mathrm{p}_{2}\right) \quad \mathrm{xf}(\alpha, \beta)\left(\mathrm{p}_{2}-\mathrm{p}_{1}\right)^{2} \mathrm{p}_{1}=$ the estimated proportion of an attribute (estimated prevalence of abortion) that is present in the urban population $\mathrm{p}_{2}=$ the estimated proportion of an attribute (estimated prevalence of abortion) that is present in the rural population $\mathrm{f}(\alpha, \beta)=$ 7.85 for $80 \%$ power with $5 \%$ significance

In this study, the level of confidence was specified at $95 \%$ and the power was fixed at $80 \%$. Specifications for $\mathrm{P}_{1}$ and $\mathrm{P}_{0}$ were based on information from available literature. The sample sizes determined for urban and rural areas were 1,417 and 601 respectively. The final sample sizes adjusted further to compensate for nonresponse rate of $20 \%$, thus the minimum for urban area was 1,181 and 501 for rural area.

\section{Selection of respondents}

The local government areas (LGA) served as the primary sampling units (PSU). The LGAs were stratified into urban-rural, based on the National Population Commission criteria. There were as twice LGAs in rural than in urban in the state. This disparity in the relative size of rural versus urban LGAs was taken into consideration in determining the number of enumeration areas (EAs) to be selected from each locality of the state. Fifty percent random samples of the total number of rural and urban LGAs were selected. The list of EAs in the selected LGAs served as the sampling frame at the second stage sampling. An EA has a population of about 500 , out of which $20 \%$ would be women aged $15-49$ years.

It was therefore estimated that each EA would provide about 100 women with an average of about two women per household. If only one woman is selected per household then we would have about 50 women in each EA. The number of EAs needed to achieve our sample size was determined based on this. The number of EAs selected as a fraction of the total gave the sampling fraction and the inverse gave the sampling interval, which was used in selecting the required EAs. In each selected EA, all households were covered. Only one respondent was selected per household. In households with more than one eligible respondent, a ballot system was used to select one.

A semi-structured questionnaire was used for data collection. It was pre-tested and administered by trained female field workers. A distinction between induced and spontaneous abortion was based on the question that sought to find out if the woman deliberately took any action in the process of stopping the pregnancy or abortion process was spontaneous. The questionnaire instrument was developed with involvement of a consultant epidemiologist at Obafemi Awolowo College of Health Sciences, Olabisi Onabanjo University, and 
Sagamu, Nigeria. A total of 2,367 (1,785 from urban area and 582 from rural area) were successfully completed.

\section{Statistical analysis}

For descriptive statistics and bivariate analysis, the Statistical Package for Social Sciences, SPSS (version 17.0) was used. Multiple logistic regression analysis was undertaking to examine how selected independent variables were related to the likelihood of unwanted pregnancy and abortion while simultaneously controlling for possible cofounders. The logistic programme was used for this purpose. Categorical attributes such as level of education, marital status and religion were converted to dichotomous variables for the purpose of logistic regression analysis.

\section{RESULTS}

A total of 2,367 (1,785 from urban area and 582 from rural area) were successfully completed.

\section{Socio-demographic Characteristics of Respondents}

The majority of respondents $(59.5 \%)$ were below 35 years. The proportion of respondents in each reproductive age group was fairly similar in urban and rural areas of the state, except that there were significantly more teenage respondents in urban area (18.2\%) than in rural area $(13.9 \%),[p<0.05]$. In both urban and rural areas of Ogun State, similar high proportion of the respondents $(60 \%, 61 \%$ respectively) was born in their respective locality.

\section{Marital status}

All the respondents responded to the question on marital status; $1,221(51.6 \%)$ of the respondents were married while $1146(48.4 \%)$ were single. About one-fifth $(21.1 \%)$ of the married respondents were in polygamous homes.

\section{Religion}

A large majority of the respondents (71.5\%) were Christians, while Muslims constituted 26.2\%. The percentages of respondents who practiced Traditional religion were $0.3 \%$ and $2 \%$ in urban and rural areas respectively.

\section{Level of Education}

In urban area of Ogun State, $42.4 \%$ of the respondents have completed secondary education and $43.4 \%$ had had post-secondary education, while in rural area the corresponding percentages were $26.3 \%$ and $21.5 \%$. The percentage of illiterate respondents was $3.5 \%$ in urban area and $4.1 \%$ in rural area. On the other hand, husbands of the respondents attained higher level of edu- cation in both areas with about $70 \%$ of them completing secondary education or higher.

\section{Occupation}

Of the 1,792 interviewees that responded to the question on occupation, $1,351(75.4 \%)$ were currently engaged in some form of economic activity. The most commonly mentioned economic activity in both the urban and rural areas of the State was trading. Other respondents were engaged in skilled and semi-skilled occupations such as hair-dressing, fashion designing, catering, etc.

\section{Awareness on Contraception}

While $91.7 \%(2,170)$ of the respondents had heard of ways or methods of preventing or avoiding pregnancy, some $(197 ; 8.3 \%)$ had not, and $746(31.5 \%)$ had tried in some way to avoid or delay pregnancy. There was a statistically significant association between level of education and use of a method to avoid or delay pregnancy $(\mathrm{p}<0.001)$.

Among respondents with no formal education, contraceptive use rate was $6 \%$ while use rate increased to $34 \%$ and $54.4 \%$ among those with secondary and postsecondary education respectively. However, there was no statistical significant difference in use rate between respondents without formal education and those with primary education. This pattern was consistent in both urban and rural areas. The current contraceptive use rate for both urban and rural areas was $21.5 \%$.

A significantly higher proportion of respondents in urban area $(27.3 \%)$ were using a contraceptive method, compared to $18.1 \%$ in rural area. Current contraceptive use rate was also significantly related to respondents' level of education. Current contraceptive use ranged from $3.5 \%$ among the illiterates to $29.1 \%$ among those with post-secondary education (Table 1).

Table 1 Contraceptive Prevalence by Level of Education

\begin{tabular}{|l|l|c|l|}
\hline $\begin{array}{l}\text { Level of Edu- } \\
\text { cation }\end{array}$ & $\begin{array}{l}\text { Number of } \\
\text { respondents }\end{array}$ & $\begin{array}{l}\text { Number } \\
\text { of cur- } \\
\text { rent } \\
\text { users }\end{array}$ & $\begin{array}{l}\text { Prevalence } \\
(\mathbf{\% )})\end{array}$ \\
\hline $\begin{array}{l}\text { No formal edu- } \\
\text { cation }\end{array}$ & 58 & 2 & 3.5 \\
\hline Part primary & 48 & 3 & 6.2 \\
\hline Primary & 63 & 8 & 12.7 \\
\hline Part secondary & 389 & 61 & 15.7 \\
\hline $\begin{array}{l}\text { Secondary } \\
\text { completed }\end{array}$ & 910 & 173 & 19.0 \\
\hline Post-secondary & 899 & 62 & 29.1 \\
\hline Total & $\mathbf{2 3 6 7}$ & $\mathbf{5 0 9}$ & $\mathbf{2 1 . 5}$ \\
\hline
\end{tabular}


Christians were more likely than their Muslim counterparts to use a contraceptive method, though the difference was marginal and non-statistically significant. When the relationship between religion and parity was explored, it was found that the Catholics and Traditionalists, on the average, had more children than those in other denominations/religions.

\section{Experience with Unwanted Pregnancy}

A total of 729 (35.9\% of 2031) respondents had been pregnant when they did not desire. The experience with unwanted pregnancy was similar in both urban (35.9\%) and rural (35.8\%) areas (Table 2).

Table 2 Reasons for termination of pregnancy

\begin{tabular}{|c|c|c|c|c|c|c|}
\hline \multirow{2}{*}{$\begin{array}{l}\text { Reason for ter- } \\
\text { mination }\end{array}$} & \multicolumn{2}{|c|}{ Urban } & \multicolumn{2}{|c|}{ Rural } & \multicolumn{2}{|c|}{ Total } \\
\hline & No. & $\%$ & No. & $\%$ & No. & $\%$ \\
\hline Not married & 72 & 13.1 & 43 & 23.9 & 115 & 15.8 \\
\hline School disruption & 105 & 19.1 & 37 & 20.6 & 142 & 19.5 \\
\hline Child too young & 120 & 21.9 & 32 & 17.7 & 152 & 20.8 \\
\hline Completed family & 94 & 17.1 & 27 & 15.0 & 121 & 16.6 \\
\hline Economic reason & 133 & 24.2 & 19 & 10.5 & 152 & 20.9 \\
\hline $\begin{array}{l}\text { Unplanned preg- } \\
\text { nancy }\end{array}$ & 6 & 1.1 & 6 & 3.3 & 12 & 1.6 \\
\hline Extramarital & 5 & 0.9 & 3 & 1.7 & 8 & 1.1 \\
\hline Paternal dispute & 5 & 0.9 & 3 & 1.7 & 8 & 1.1 \\
\hline Others & 3 & 0.6 & 7 & 3.9 & 10 & 1.4 \\
\hline No reason & 6 & 1.1 & 3 & 1.7 & 9 & 1.2 \\
\hline Total & 549 & 100.0 & 180 & 100.0 & 729 & 100.0 \\
\hline
\end{tabular}

The reasons most commonly given in urban area for not wanting the pregnancy were financial- high cost of raising children $(24.2 \%)$, short birth intervals or poor timing of pregnancies $(21.9 \%)$, desire to continue with education (19.1\%) and having completed family size $(17.1 \%)$.

In rural area, the single most important reason was that the respondents were unmarried and did not wish to be seen as unwed mothers $(23.9 \%)$. Desire to continue education $(20.6 \%)$, poor birth spacing $(17.7 \%)$ and having completed family size $(15.0 \%)$ were the other major reasons. Of the 729 respondents who had experienced unwanted pregnancies, 143 (19.6\%) became pregnant while using some form of contraception. Contraceptive failure rate was significantly higher in rural area $(22.9 \%)$ than in urban area $(17.2 \%)$. Of those who became pregnant while using a method, 37 (25.9\%) was on the pill and $42(29.3 \%)$ were using rhythm method.

\section{Prevalence of Abortion}

The prevalence of abortion in this study was $33.5 \%$ for the state; and $34.8 \%$ and $29.4 \%$ in urban and rural areas of Ogun State respectively. The difference was not statistically significant $(\mathrm{p}=0.3642841)$. The prevalence of abortion in both urban and rural areas was strongly related to the level of education of respondents (Table 3).

Table 3 Respondents' Level of Education and Prevalence of Abortion in Urban Rural areas of Ogun State

\begin{tabular}{|l|l|l|l|l|l|l|}
\hline \multirow{2}{*}{$\begin{array}{l}\text { Level of Edu- } \\
\text { cation }\end{array}$} & \multicolumn{2}{|l|}{$\begin{array}{l}\text { No. of re- } \\
\text { spondents }\end{array}$} & \multicolumn{2}{l|}{$\begin{array}{l}\text { pre No. with } \\
\text { history } \\
\text { abortion }\end{array}$} & \multicolumn{2}{l|}{ Prevalence \% } \\
\cline { 2 - 7 } & Urban & Rural & Urban & Rural & Urban & rural \\
\hline $\begin{array}{l}\text { No formal } \\
\text { education }\end{array}$ & 41 & 17 & 5 & 2 & 12.2 & 11.7 \\
\hline Part Primary & 35 & 13 & 6 & 2 & 17.1 & 15.3 \\
\hline Primary & 46 & 17 & 9 & 3 & 18.5 & 17.6 \\
\hline $\begin{array}{l}\text { Part Second- } \\
\text { ary }\end{array}$ & 292 & 97 & 74 & 21 & 25.3 & 21.7 \\
\hline $\begin{array}{l}\text { Secondary } \\
\text { Completed }\end{array}$ & 682. & 228 & 228 & 69 & 33.4 & 30.7 \\
\hline $\begin{array}{l}\text { Post- } \\
\text { Secondary }\end{array}$ & 689 & 210 & 299 & 74 & 43.4 & 35.2 \\
\hline Total & $\mathbf{1 7 8 5}$ & $\mathbf{5 8 2}$ & $\mathbf{6 2 1}$ & $\mathbf{1 7 1}$ & $\mathbf{3 4 . 8}$ & $\mathbf{2 9 . 4}$ \\
\hline
\end{tabular}

The prevalence of abortion increased with increasing level of education in both urban and rural areas of the State. It was also observed that some of the attempts at termination did not succeed. Failure rate (Table 4) was related to the respondents' level of education. It was lowest $(0 \%)$ among those with post-secondary education and highest $(21.4 \%)$ among those with no formal education.

Abortion prevalence rate was lowest among teenage respondents and highest among women between the ages of 25 and 34 years. The prevalence of abortion was consistently lower among Muslims than Christians. Abortion prevalence was fairly evenly distributed among the different denominations.

Table 4 Failed attempts to stop a Pregnancy by Level of Education

\begin{tabular}{|l|c|c|c|}
\hline $\begin{array}{l}\text { Level of Educa- } \\
\text { tion }\end{array}$ & $\begin{array}{l}\text { No. of re- } \\
\text { spondents } \\
\text { who attempt- } \\
\text { ed }\end{array}$ & $\begin{array}{l}\text { No. of } \\
\text { failures }\end{array}$ & Percentage \\
\hline $\begin{array}{l}\text { No formal educa- } \\
\text { tion }\end{array}$ & 14 & 3 & 21.4 \\
\hline Part primary & 12 & 2 & 16.7 \\
\hline Primary & 15 & 2 & 13.3 \\
\hline Part secondary & 93 & 9 & 9.3 \\
\hline $\begin{array}{l}\text { Secondary com- } \\
\text { pleted }\end{array}$ & 218 & 7 & 3.2 \\
\hline Post-secondary & 216 & 0 & 0.0 \\
\hline Total & $\mathbf{5 6 8}$ & $\mathbf{2 3}$ & $\mathbf{4 . 1}$ \\
\hline
\end{tabular}

\section{Decision to Terminate Pregnancy}

The decision to stop pregnancy was made by both the man and the woman in majority $(53.8 \%)$ of the cases. 
In $43 \%$ of the cases, the decision was made solely by the woman; and in $0.7 \%$, the male partner independently made the decision. The decision-making pattern was similar in both urban and rural areas of Ogun State. Ninety percent of the respondents had informed their male partners of the plan to terminate the pregnancy. About one-quarter (24.1\%) of the respondents who had experienced unwanted pregnancy, had more than one experience and many had terminated more than three pregnancies.

\section{Timing of Termination}

Almost all the terminations (94.2\%) took place within the first three months of the pregnancy. However, there were cases where the pregnancies were terminated after the fourth month $(2.1 \%)$. An overwhelming majority of the terminations $(84.6 \%)$ were done at private clinics or hospitals (Table 5). Respondents from rural area were more likely to use traditional healers and chemist operators.

Table 5 Place where pregnancies were terminated by respondents

\begin{tabular}{|c|c|c|c|c|c|c|}
\hline Place & \multicolumn{2}{|c|}{$\begin{array}{ll}\text { Urban } & \\
\text { No. } & \%\end{array}$} & \multicolumn{2}{|c|}{ Rural } & \multicolumn{2}{|l|}{ Total } \\
\hline $\begin{array}{ll}\text { Private clin- } \\
\text { ic/hospital }\end{array}$ & 533 & 85.8 & 137 & 80.1 & 670 & 84.6 \\
\hline Nurse's home & 11 & 1.8 & 2 & 1.2 & 13 & 1.6 \\
\hline Doctor's home & 9 & 1.5 & 5 & 2.9 & 14 & 1.8 \\
\hline Chemist shop & 19 & 3.0 & 9 & 5.3 & 28 & 3.5 \\
\hline $\begin{array}{l}\text { Respondent's } \\
\text { home }\end{array}$ & 11 & 1.8 & 2 & 1.2 & 13 & 1.6 \\
\hline $\begin{array}{l}\text { Materni- } \\
\text { ty/Nursing home }\end{array}$ & 25 & 4.0 & 4 & 2.3 & 29 & 3.7 \\
\hline $\begin{array}{l}\text { Traditional } \\
\text { healer }\end{array}$ & 13 & 2.1 & 12 & 7.0 & 25 & 3.2 \\
\hline Total & 621 & 100.0 & 171 & 100.0 & 792 & 100.0 \\
\hline
\end{tabular}

\section{Reasons for Choosing a Place for Pregnancy Termi-} nation

Quality of service was the most important factor in the choice of a place for pregnancy termination in both urban and rural areas, accounting for $53.5 \%$ and $57.3 \%$ respectively (total, 55.6\%). The next most important factor was direction by a friend (urban 20.1\%, rural $16.3 \%$, and total $18.8 \%$ ). Other important factors were having used the facility before (total 9.6\%) and direction by a sister (total $8.4 \%$ ). Cost consideration (total, $0.4 \%$ ) was a rather insignificant determinant of choice.

\section{Methods Used to Terminate Pregnancy}

Manual vacuum aspiration was the most common $(81.2 \%)$ technique used to terminate pregnancies. Medical practitioners largely did the terminations. Nurses, chemist operators and traditional healers were involved in $5.3 \%, 3.5 \%$ and $3.2 \%$ respectively. Advice on con- traception was provided to $67 \%$ and $50.1 \%$ of patients in urban and rural areas respectively.

\section{Abortion-Associated Complications}

Complaints and complications following abortion were significantly $(\mathrm{p}=0.186778)$ more common in rural $(17.7 \%)$ than urban $(7.1 \%)$ area. The most commonly reported complaints following abortion were abdominal pain $(40.2 \%)$, bleeding per vaginam $(33.6 \%)$ and infection $(12.7 \%)$. Of the 65 patients with complaints, $58(89.2 \%)$ were given some form of treatment mainly at private clinics/hospitals.

\section{Perceived Frequency of Abortion and Reasons for Abortion in the Community}

About two-thirds (63.9\%) of the rural respondents considered abortion rates to be high or very high in their respective communities, whereas a third (33.7\%) thought so in urban area (total $41.2 \%$ ). Economic reasons (high cost of raising children) were often cited as reasons women make use of abortion services. Being single and would not want to be seen as unwed single mother was the second important reason. Responds were of the opinion that pregnancy could be safely terminated by a qualified medical practitioner and that the decision to stop a pregnancy should be jointly made by both partners.

Factors significantly related to the likelihood of unwanted pregnancy after controlling for confounders were age, marital status and level of education (Table $6)$.

The educational level of the spouse was also positively associated with the risk of unwanted pregnancy but the association was not statistically significant $(p=0.12)$.

Table 6 Linear regression showing the Relationship between Selected Independent Variables and the likelihood of Unwanted Pregnancy

\begin{tabular}{|l|l|l|l|l|l|}
\hline Model & \multicolumn{2}{|l|}{$\begin{array}{l}\text { Unstandardized } \\
\text { coefficient }\end{array}$} & \multirow{2}{*}{ Beta } & $\mathrm{t}$ & Sig. \\
\cline { 2 - 3 } & $\mathrm{B}$ & Std. Error & & & \\
\hline Constant & 0.642 & 0.320 & & 2.029 & 0.32 \\
\hline Age & 0.215 & 0.107 & 0.143 & 2.457 & 0.032 \\
\hline $\begin{array}{l}\text { Educational } \\
\text { level }\end{array}$ & 0.258 & 0.122 & 0.165 & 2.712 & 0.012 \\
\hline Marital status & 0.237 & 0.118 & 0.137 & 2.376 & 0.041 \\
\hline
\end{tabular}

For abortion, the only factor that remained statistically significant after controlling for confounders was the level of education (Table 7). 
Table 7 Linear regression showing the Relationship between Selected Independent Variables and the likelihood of Induced Abortion

\begin{tabular}{|l|l|l|l|l|l|}
\hline Model & \multicolumn{2}{|l|}{$\begin{array}{l}\text { Unstandardized coeffi- } \\
\text { cient }\end{array}$} & Beta & $\mathrm{t}$ & Sig. \\
\cline { 2 - 5 } & $\mathrm{B}$ & Std. Error & & & \\
\hline Constant & 0.622 & 0.303 & & 2.049 & 0.42 \\
\hline Age & 0.021 & 0.011 & 0.138 & 1.957 & 0.052 \\
\hline $\begin{array}{l}\text { Educational } \\
\text { level }\end{array}$ & 0.254 & 0.110 & 0.155 & 2.312 & 0.022 \\
\hline $\begin{array}{l}\text { Marital } \\
\text { status }\end{array}$ & 0.140 & 0.074 & 0.135 & 1.886 & 0.061 \\
\hline
\end{tabular}

Those with secondary education and above were more likely ( $p=0.006$ ) to be involved in abortion than the less educated responds.

\section{DISCUSSION}

The prevalence of unintended (unwanted) pregnancy of $31.1 \%$ in this study was significantly higher than $19 \%{ }^{16}, 21.7 \%{ }^{8}$ and $26.6 \%^{2}$ reported in earlier studies from Southwestern Nigeria in 1980, 1982 and 2004 respectively and $20 \%$ reported from Jos and Ife in 1996. ${ }^{10}$ However, it was much lower than $43.6 \%$ reported from Ghana. ${ }^{17}$

Abortion is a matter with such stigma that many people who are directly or indirectly involved more often than not, avoid discussion on or out rightly deny involvement except when confidentiality is provided. Therefore, an abortion prevalence of $33.5 \%$ in this study was unexpectedly quite high, far higher than $21.7 \%, 5.6 \%$ and $5.0 \%$ from earlier studies from Southwestern Nigeria. The previous reports had acknowledged the probability of gross under-reporting of the incidence of abortion in that study.

It is possible that with the steps taken in this study it was possible to ensure more confidentiality and get more respondents to be forthcoming with information on abortion. It is also true that more people, with enlightenment, can speak much more freely on the subject of unwanted pregnancy and abortion once they are ensured of confidentiality. In spite of this, because of adverse societal perception of abortion, it is still probable that some women may not have owned up to induced abortion. Therefore, the actual figure may be more than reported. It is also possible that there has been an actual increase in the abortion prevalence over the years because of worsening economic situation in the country.

Abortion was more prevalent (though not significantly different, $\mathrm{OR}=1.32, \mathrm{p}=0.82$ ) among respondents from urban $(34.8 \%)$ than rural $(29.4 \%)$ and was not confounded by age or levels of education.
This may be reflective of economic pressure of urban life and better access to safer (modern) methods of pregnancy termination.

Education appeared to play a significant role in abortion as the prevalence of abortion increased with increasing level of education. This is similar to earlier reports from Nigeria and Ghana., ${ }^{2,10,17}$ More educated women probably wish to pursue careers or further their education, which pregnancy may interrupt or make more stressful. In this study, interruption of education accounted for $19.5 \%$ of the reasons respondents did not want their pregnancy.

Those without formal education or with low educational level may not even realize that they are pregnant until it has become too late, and they may not be able to negotiate with their spouses with regards to safe sex. This is also ironical because one would have expected the more educated respondents to be more aware of contraception; the risks of unprotected sexual intercourse and unsafe abortion and as such take steps to prevent it. Doctors provided abortion services for a large majority of unwanted pregnancies (86.4\%), which is consistent with findings from other studies in the country ${ }^{5,18,19}$.

Economic reasons, child too young, school disruption and being unmarried were the commonest reasons given for terminating unwanted pregnancy. All these are also reasons for which effective contraception would be recommended to sexually active adults. Similar findings were reported Southwestern Nigeria ${ }^{2,8}$ and Ghana $^{17}$, where socio-economic were most commonly cited for terminating unwanted pregnancy. Contraception, which would have prevented unwanted pregnancies in these situations, is definitely cheaper than the abortion both on the short and long runs.

The fact that large majority $(51.6 \%)$ of the respondents who were married contributed significantly to the prevalence of abortion further supports findings from other studies that the problem of unwanted pregnancy and abortion pervades women of all ages and marital status. $^{2,10}$ The adolescents and young persons, however, gain prominence in unsafe abortion because of their financial incapacitation and often illicit and spontaneous nature of the sexual act itself. They tend to seek help from unskilled abortion care providers, while the married women may get help from their husbands and so seek safe abortion services.

Majority of the respondents (91.7\%) were aware of some methods of contraception. This is similar to findings from earlier studies from Southwestern Nigeria ${ }^{2,8}$. 
Despite this high level of awareness, only $21.5 \%$ of women had tried contraception at some point, showing a great gap between awareness and usage. The overall conclusion would be that knowledge does not translate into a change in attitude where contraceptive usage is concerned. $^{6,8}$

Therefore, further research is necessary to study the possible factors that could affect this change. Possible factors that need to be investigated include fear of sideeffects, misinformation on contraception, spousal disapproval, adolescent discrimination in the use of contraception and fear of being wayward for using contraception, among others. $^{20,21,22}$

In addition, despite the high association between education and use rate of contraception, this same group also had a high association with abortion. Similar findings were reported from earlier studies from Southwestern Nigeria and elsewhere, indicating that women who had used contraception are more likely to have had abortion than women who had not used contraception $^{8,10}$. The prevalence of abortion was lower among Moslems in this study despite the fact that the larger majority of the study population in the study areas was Christians.

Notably, cost $(0.4 \%)$ was not a consideration in the choice of a place for termination of pregnancy as was the quality of service $(55.6 \%)$. This is probably the reason many of them are alive today to partake in the study! Those who had unsafe abortion would probably have suffered mortality. Friends played a significant role $(18.8 \%)$ in the choice of a facility for termination of pregnancy. This compares with other reports in which peer groups have been identified as playing significant roles in unwanted pregnancy and induced abortion $^{23}$. Thus, strategies to stem down the high waive of unwanted pregnancy and unsafe abortion must focus on these groups generally in order to ensure effective dissemination of information. Finally, $41.2 \%$ of women rate the prevalence of abortion as being high or very high in the community.

\section{RECOMMENDATIONS}

Firstly, public enlightenment on sexuality education and contraception, which will prevent both unwanted pregnancies and sexually transmitted diseases, should be extended to all members of the community, both rural and urban, since induced abortion is not restricted to any female subgroup. A basic level of education of at least junior secondary education (equivalent to 9 years of education) should be made compulsory while reproduction and family planning should be incorporated into social studies.
Secondly, contraceptive services should be made available at no or low cost to members of the community so as to prevent unwanted pregnancies.

Thirdly, most abortions carried out by medical practitioners were safe. Therefore, policy changes should be encouraged to ensure availability and accessibility of safe abortion services. These changes are expected to occur both at legislative and hospital management levels.

Fourthly, advocacy to see unsafe abortion and its consequences as a major reproductive health challenge should be addressed from the perspective of preserving lives and rights of women rather than from criminal point of view.

\section{CONCLUSION}

Unwanted pregnancy constitutes a problem, even at the community level. The high contraceptive awareness should be translated to an increased use so as to bridge the large gap of unmet need. This is a task for policymakers, non-governmental organizations, community and opinion leaders, health professional bodies and family planning service providers. Increased contraceptive use will reduce the prevalence of unwanted pregnancy and induced abortion, with all the inherent complications, when performed clandestinely by unskilled abortion care providers under the current restrictive legal environment in Nigeria.

\section{REFERENCES}

1. Otoide VO, Oronsanye F, Okonofua FE. Why Nigerian adolescents seek abortion rather than contraception: Evidence from focus group discussions. Int Fam Plann Perspect. 2001; 27(2): 77-81.

2. Oye-Adeniran BA, Adewole IF, Umoh AV, et al. Community-based survey of unwanted pregnancy in southwestern Nigeria. Afr J Reprod Health. 2004; 8(3): 103-115.

3. Abiodun OM, Balogun OR. Sexual activity and contraceptive use among young female students of tertiary educational institution in Ilorin, Nigeria. Contraception. 2009;79:146-9.

4. Oriji VK, Jeremiah I, Kasso T. Induced abortion amongst undergraduate students of University of Port Harcourt. Nig J Med. 2009;18(2): 199-202.

5. Henshaw SK, Singh S, Oye-Adeniran BA, Adewole IF, Iwere N, Cuca YP. The incidence of induced abortion in Nigeria. Int Fam Plann Persp. 1998;24(4): 156-164.

6. Adewole IF, Oye-Adeniran BA, Iwere $\mathrm{N}$, Oladokun O, Gbadegesin A, Babarinsa AI. Contraceptive usage among abortion seekers in Nigeria. W Afr J Med 2002;21(2): 112-4. 
7. Alan Guttmacher Institute. Shaing Responsibilty: Women, Society and Abortion Worldwide. New York: The Alan Guttmacher Institute, 1999.

8. Olukoya AA. Pregnancy termination: results of a community-based study in Lagos. Int J Gynaecol Obstet 1987;25: 41-46.

9. Monjok E, Smesny A, Essien EJ. Contraceptive practices in Nigeria: Literature review and recommendation for future policy decisions. Open $A c$ cess J Contracept 2010;1: 9-22.

10. Oye-Adeniran BA, Adewole IF, Odeyemi KA, Ekanem EE, Umoh AV. Contraceptive prevalence among young women in Nigeria. J Obstet Gynaecol. 2005;25: 182-5.

11. Amazigo U, Silva N, Kaufman J, Obikeze DS. Sexual activity and contraceptive knowledge and use among in-school adolescents in Nigeria. Int Fam Plann Persp. 1997;23:28-33.

12. Opkani AOU, Okpanu JU. Sexual activity and contraceptive use among female adolescents: A report from Port Harcourt. Afr J Reprod Health. 2000;4:40-47.

13. Bankole A, Sedgh G, Okonofua F, Imarhiagbe C, Hussain R, Wulf D. Barriers to safe motherhood in Nigeria. New York, NY: The Alan Guttmacher Institute; 2009.

14. Okonofua FE, Odimegwu E, Ajabor H, et al. Assessing the prevalence and determinants of unwanted pregnancy and induced abortion in Nigeria. Stud Fam Plann 1999;30(1):67-77.

15. Benson J, Nicholson LA, Gaffikin L, Kinoti SN. Complications of unsafe abortion in sub-Saharan Africa: a review. Health Policy Plan 1996;11(2): 117-131.
16. Makinwa-Adebusoye PK, Nicholas DJ and Kelly SE. Contraception and Breastfeeding Study: Final report. Center for Social Culture and Environmental Research, University ofBenin, Benin City, Nigeria, 1982.

17. Geelheod D, Nayembil D, Asare K, Van Leeuwen $\mathrm{JH}$ and Van Roosmalen J. Gender and unwanted pregnancy: a community-basd study in rural Ghana. J Obstet Gynaecol 2002;23(4):249-255.

18. Adewole IF, Oye-adeniran BA, Iwere $\mathrm{N}$, Oladokun A and Gbadegesin A. Terminating an unwanted pregnancy the economic implications in Nigeria. J Obstet Gynaecol 2002;34:163-167.

19. Adewole IF. Trends in post-abortal mortality and morbidity in Nigeria in Ibadan, Nigeria. Int $J G y$ naecol Obstet 1992;38(1):39-44.

20. Onuzurike BK and Usochukwu BSC. Knowledge, attitude and practice of family planning amongst women in a high density low income urban of Enugu, Nigeria. Afr $J$ Reprod Health 2001;5(2):83-89.

21. Aziken ME, Okonta PI and Ande BAA. Knowledge and perception of emergency contraception among female Nigerian undergraduates. Int Fam Plann Persp 2003;29(2):84-87.

22. Otoide VO, Oronsanye F and Okonofua FE. Why Nigerian adolescents seek abortion rather than contraception: evidence from focus group discussions. Int Fam Plann Persp 2001;27(2):77-81.

23. Unuigbe IE and Ogbeide O. Sexual behavior and perception of AIDS among adolescent girls in Benin City, Nigeria. Afr $J$ Reprod Health 1999;3(1):39-44. 